\title{
FAKTOR-FAKTOR YANG MEMPENGARUHI STRUKTUR MODAL PADA PERUSAHAAN WHOLESALE AND RETAIL TRADE DI BURSA EFEK INDONESIA
}

\author{
JOANA L. SARAGIH \\ Fakultas Ekonomi Program Studi Akuntansi Universitas Katolik Santo Thomas \\ saragihjoana@yahoo.co.id
}

\begin{abstract}
ABSTRAK
Penelitian ini bertujuan untuk menguji pengaruh current ratio dan debt ratio terhadap return on investment pada Perusahaan Retail And Wholesale di Bursa Efek Indonesia. Populasi penelitian adalah seluruh perusahaan Retail And Wholesale yang terdaftar di Bursa Efek Indonesia tahun 2012-2014. Metode pengambilan sampel adalah purposive sampling sehingga sampel penelitian sebanyak 15 perusahaan. Teknik analisis data yang digunakan adalah regresi linear berganda. Dari hasil pembahasan disimpulkan bahwa persamaan regresi linear berganda yang diperoleh adalah $\mathrm{Y}=13,914-0,400 \mathrm{X} 1$ + 0,038 X2 - 10,457 X3 . Artinya, Ukuran Perusahaan dan Return On Assets mempunyai pengaruh negatif signifikan terhadap Debt To Equity Ratio dan Petumbuhan Aktiva Tidak berpengaruh terhadap Debt To Equity Ratio pada perusahaan Retail And Wholesale di Bursa Efek Indonesia. Hal ini dapat dilihat dari nilai koefisien regresinya. Nilai koefisien determinan menunjukkan bahwa return on investment dapat dijelaskan oleh current ratio dan debt ratio sebesar 17,6 \%, sedangkan 22,4 \% dijelaskan oleh faktor lain. Dilihat dari uji t, Ukuran Perusahaan berpengaruh negatif dan signifikan terhadap Debt To Equity Rati, Pertumbuhan Aktiva tidak berpengaruh terhadap Debt To Equity Rati, dan Return On Assets berpengaruh positif dan signifikan terhadap Debt To Equity Ratio pada perusahaan Retail And Wholesale di Bursa Efek Indonesia.
\end{abstract}

Kata kunci : Struktur Modal , Ukuran Perusahaan, Pertumbuhan Aktiva, Profitabilitas

\section{PENDAHULUAN}

Umumnya perusahaan cenderung menggunakan modal sendiri sebagai modal permanen dan modal asing hanya digunakan sebagai pelengkap apabila dana yang dibutuhkan kurang mencukupi.

Penentuan proporsi hutang dan modal dalam penggunaannya sebagai sumber dana perusahaan berkaitan erat dengan istilah struktur modal. Struktur modal adalah perimbangan atau perbandingan antara jumlah hutang jangka panjang dengan modal sendiri.

Ukuran Perusahaan merupakan ukuran atau besarnya asset yang dimiliki perusahaan, Nilai total aset yang besar lebih cenderung memiliki sumber permodalan yang lebih terdiversifikasi sehingga semakin kecil kemungkinan bangkrut dan lebih mampu memenuhi kewajibannya, sehingga perusahaan besar cenderung memiliki hutang lebih besar. 
Pertumbuhan Aktiva perusahaan menjadi salah satu faktor dalam menilai kemampuan perusahaan dalam membayar hutangnya dan kemudahan perusahaan untuk memperoleh pendanaan eksternal.

Profitabilitas menunjukkan seberapa besar kemampuan perusahaan dalam menghasilkan laba selama periode tertentu yang akan memberikan gambaran singkat mengenai efektivitas manajemen dalam melaksanakan operasionalnya.

\section{TELAAH TEORI DAN PENGEMBANGAN HIPOTESIS}

\section{Telaah Teori}

\section{a. Struktur Modal}

Menurut Brigham dan Houston (2001), modal adalah jumlah dari hutang jangka panjang, saham preferen dan ekuitas saham biasa atau mungkin pos-pos tersebut ditambah hutang jangka pendek yang dikenakan bunga. Modal terdiri dari modal asing dan modal sendiri.

Menurut Riyanto (2001) dilihat dari asalnya sumber modal terdiri dari sumber internal adalah modal yang dihasilkan sendiri didalam perusahaan dan sumber eksternal yaitu dana yang diperoleh dari luar perusahaan dengan menerbitkan saham atau obligasi.

Menurut Ambarwati (2010), struktur modal adalah kombinasi atau perimbangan antara hutang dan modal sendiri (saham preferen dan saham biasa) yang digunakan perusahaan untuk merencanakan mendapatkan modal. Jika kombinasi ideal ini dapat diciptakan, maka saham perusahaan akan mencapai harga maksimal dan struktur modal yang digunakan merupakan struktur modal yang optimal.

\section{b. Ukuran Perusahaan}

Ukuran perusahaan merupakan ukuran atau besarnya aset yang dimiliki oleh perusahaan. Semakin besar ukuran suatu perusahaan, maka kecenderungan menggunakan modal asing juga akan semakin besar. Hal ini disebabkan karena perusahaan besar membutuhkan dana yang besar pula untuk menunjang operasionalnya dan salah satu alternatif pemenuhannya adalah dengan modal asing apabila modal sendiri tidak mencukupi.

\section{c. Pertumbuhan Aktiva}

Asset merupakan aktiva yang digunakan untuk aktivitas operasional perusahaan. Semakin besar asset diharapkan semakin besar hasil operasional yang dihasilkan oleh perusahaan. Peningkatan asset yang 
diikuti peningkatan hasil operasi akan semakin menambah kepercayaan pihak luar terhadap perusahaan. Dengan meningkatnya kepercayaan pihak luar terhadap perusahaan, maka proporsi hutang semakin lebih besar daripada modal sendiri. Hal ini didasarkan pada keyakinan kreditor atas dana yang ditanamkan ke dalam perusahaan dijamin oleh besarnya asset yang dimiliki perusahaan.

\section{d. Profitabilitas}

Menurut Kasmir (2010) profitabilitas merupakan rasio untuk menilai kemampuan perusahaan dalam mencari keuntungan. Perusahaan dengan profitabilitas tinggi akan semakin rendah kebutuhan dana asing (hutang) sehingga semakin rendah pula rasio struktur modalnya. Akan tetapi, perusahaan dengan profitabilitas tinggi akan lebih mudah melakukan pendanaan eksternal, sehingga hubungan antara profitabilitas terhadap struktur modal bisa menjadi positif. Rasio Tingkat Pengembalian atas Investasi terdiri atas:

1. Hasil PengembalianatasAset (Return on Assets)

Hasil pengembalianatasaset $=\frac{\text { Laba Bersih }}{\text { Total } \text { Aset }}$

2. Hasil PengembalianatasEkuitas (Return on Equity)

Hasil pengembalianatasekuitas $=\frac{\text { Laba Bersih }}{\text { Total Ekuitas }}$

\section{Pengembangan Hipotesisi}

a. Pengaruh Ukuran Perusahaan terhadap Struktur Modal

Perusahaan dengan ukuran lebih besar, mempunyai kepercayaan lebih besar dalam mendapatkan sumber dana, sehingga akan memudahkan untuk mendapatkan kredit dari pihak luar. Teori asimetri (asymmetric theory) mengasumsikan bahwa perusahaan yang lebih besar memiliki ketidakseimbangan informasi yang lebih kecil. Hal ini memudahkan perusahaan dalam hal pendanaan eksternal. Oleh karena itu, ukuran perusahaan yang besar merupakan sinyal positif bagi kreditur untuk memberikan pinjaman. Maka dapat dikatakan bahwa ukuran perusahaan berpengaruh positip terhadap struktur modal perusahaan.

\section{b. Pengaruh Pertumbuhan Aktiva terhadap Struktur Modal}

Pecking order theory menyatakan bahwa perusahaan dengan tingkat pertumbuhan yang tinggi akan melakukan ekspansi dengan cara menggunakan dana eksternal berupa hutang. Terjadinya peningkatan asset yang diikuti peningkatan hasil operasi akan semakin menambah 
kepercayaan pihak luar terhadap perusahaan. Dengan meningkatnya kepercayaan pihak luar terhadap perusahaan, maka proporsi hutang akan semakin lebih besar daripada modal sendiri.

\section{c. Pengaruh Profitabilitas terhadap Struktur Modal}

Perusahaan dengan tingkat pengembalian yang tinggi atas investasi menggunakan hutang yang relatif kecil dan tidak memerlukan banyak pembiayaan dengan hutang. Tingkat pengembaliannya yang tinggi memungkinkan mereka untuk membiayai sebagian besar kebutuhan pendanaan mereka dengan dana yang dihasilkan secara internal.

Implikasi dari pecking order theory menyebutkan bahwa perusahaan yang kurang profitable akan cenderung mempunyai hutang yang lebih besar karena dua alasan, yaitu dana internal tidak cukup dan hutang merupakan sumber eksternal yang lebih disukai. Pecking order theory juga menjelaskan bahwa perusahaan yang profitable umumnya meminjam dalam jumlah sedikit bukan karena mereka mempunyai target debt ratio yang rendah, tetapi karena mereka memerlukan external financing yang sedikit.

\section{Hipotesis}

Hipotesis dalam penelitian ini adalah

H1: Ukuran perusahaan, berpengaruh positif signifikan terhadap struktur modal pada perusahaan Wholesale And Retail Trade Di Bursa Efek Indonesia tahun 2012-2014.

H2: Pertumbuhan aktiva, berpengaruh positif signifikan terhadap struktur modal pada perusahaan Wholesale And Retail Trade Di Bursa Efek Indonesia tahun 2012-2014.

H3: Profitabilitas berpengaruh negatif signifikan terhadap struktur modal pada perusahaan Wholesale And Retail Trade Di Bursa Efek Indonesia tahun 2012-2014

\section{MOTODE PENELITIAN}

\section{Populasi dan Sampel}

Populasi dalam penelitian ini adalah seluruh perusahaan Wholesale And Retail Trade yang terdaftar di Bursa Efek Indonesia pada tahun 20122014. Pengambilan sampel dilakukan dengan metode purposive sampling, yaitu pengambilan sampel yang berdasarkan kriteria tertentu, dengan demikian sampel untuk penelitian ini sebanyak 15 perusahaan. 


\section{Operasionalisasi Variabel}

a. Struktur Modal (Y)

Struktur modal adalah perbandingan antara hutang jangka panjang dengan modal sendiri. Struktur modal dalam penelitian ini diukur dengan rasio debt to equity ratio (DER), yaitu:

b. Ukuran Perusahaan $\left(\mathrm{X}_{1}\right)$

$$
\text { DER }=\frac{\text { Total Hutang }}{\text { Total Ekuitas }}
$$

Ukuran Perusahaan merupakan besarnya asset yang dimiliki perusahaan.yang diukur dengan menggunakan logaritma natural (Ln) dari total aktiva. Rumus yang digunakan,

Ukuran perusahaan $=$ Ln $($ Total Aktiva $)$

c. Pertumbuhan Aktiva $\left(\mathrm{X}_{2}\right)$

Pertumbuhan aktiva menunjukkan perubahan (peningkatan atau penurunan) total aktiva yang dimiliki oleh perusahaan. Pertumbuhan aktiva (GROWTH) diukur dengan rumus : Pertumbuhan Aktiva $=$

$$
\frac{\mathrm{TA}_{\mathrm{t}}-\mathrm{TA}_{\mathrm{t}-1}}{\mathrm{TA}_{\mathrm{t}-1}}
$$

Dimana: $\mathrm{TA}_{\mathrm{t}}=$ Total aktiva tahun ke- $\mathrm{t}$

$\mathrm{TA}_{\mathrm{t}-1}=$ Total aktiva tahun sebelumnya

d. Profitabilitas $\left(\mathrm{X}_{3}\right)$

Profitabilitas yaitu variabel yang menunjukkan kemampuan perusahaan dalam memperoleh laba. Profitabilitas dalam penelitian ini diukur dengan rasio Hasil Pengembalian atas Aset (Return on Assets).Nilai hasil pengembalian atas aset dapat dihitung dengan rumus :

Hasil pengembalianatasaset $=\frac{\text { Laba Bersih }}{\text { Total Asset }}$

\section{Pengujian Asumsi Klasik}

a. Uji Normalitas

Jika data menyebar di sekitar garis diagonal dan mengikuti arah garis diagonal, maka model regresimemenuhiasumsinormalitas.Jika data menyebarjauhdari garis diagonal dan/atau tidak mengikuti arah garis diagonal, maka model regresi tidak memenuhi asumsi normalitas. 
b. Uji Multikolinieritas

ApabilanilaiTollerance > 0,10 dan VIF (Variance Inflation Factors)

$<10$ maka tidak terjadi multikolinieritas.

Apabila nilai Tollerance $<0,10$ dan VIF (Variance Inflation Factors) $>10$ maka terjadi multikolinieritas.

c. Uji Autokorelasi

Autokorelasidalampenelitianinidapatdilihatdenganmenggunakan uji

Durbin-Watson :

Tabel 1. Statistik Durbin-Watson (DW test)

\begin{tabular}{|l|l|l|}
\hline Hipotesis Nol & Keputusan & Jika \\
\hline Tidak ada autokrelasi positif & Tolak & $0<\mathrm{d}<\mathrm{dl}$ \\
\hline Tidak ada autokorelasi positif & Tanpa kesimpulan & $\mathrm{dl} \leq \mathrm{d} \leq \mathrm{du}$ \\
\hline Tidak ada autokorelasi negative & Tolak & 4-dl $<\mathrm{d}<4$ \\
\hline Tidak ada autokorelasi negative & Tanpa kesimpulan & 4 -du $\leq \mathrm{d} \leq 4$-dl \\
\hline $\begin{array}{l}\text { Tidak ada autokorelasi positif atau } \\
\text { negative }\end{array}$ & Tidak ditolak & $\mathrm{du}<\mathrm{d}<4$-du \\
\hline
\end{tabular}

Sumber: Ghozali (2005)

Jika ada pola tertentu, seperti titik-titik yang ada membentuk pola tertentu yang teratur (bergelombang, melebar kemudian menyempit), maka mengindikasikan telah terjadi heteroskedastisitas. Jika tidak ada pola yang jelas, serta titik-titik menyebar di atas dan di bawah angka 0 pada sumbu Y, maka tidak terjadi heteroskedastisitas.

\section{Teknik Analisis Data}

Teknikanalisis data dalampenelitianiniadalahanalisisregresi linier berganda, dengan model dasar :

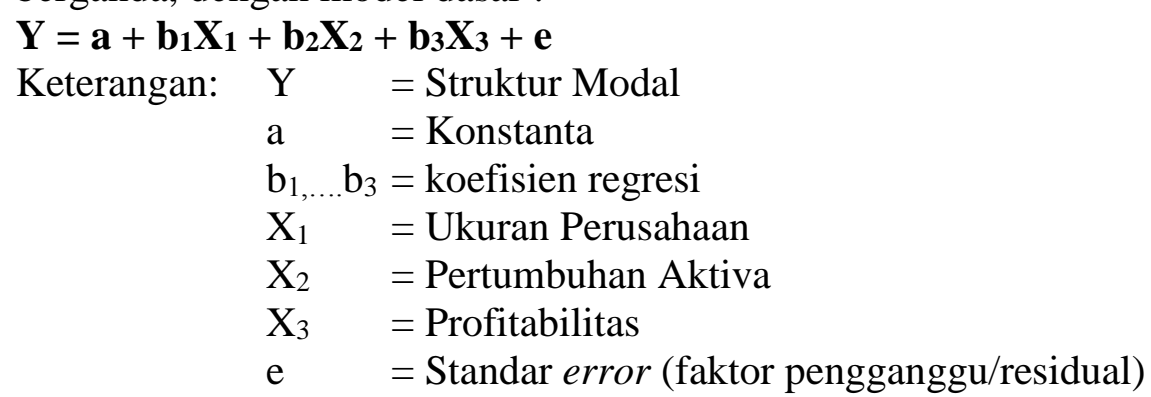




\section{Pengujian Hipotesis}

Pengujian ini merupakan suatu prosedur dimana hasil sampel yang digunakan untuk menguji kebenaran suatu hipotesis dengan alat analisis yaitu uji t, dan uji F.

a. Uji t (Uji Parsial)

Pengujian ini dilakukan untuk mengetahui pengaruh ukuran perusahaan, pertumbuhan aktiva, dan profitabilitas, secara parsial terhadap struktur modal pada perusahaan Wholesale And Retail Trade yang terdaftar di Bursa Efek Indonesia untuk periode 2012-2014.

b. Uji F (Uji Simultan)

Uji ini dilakukan untuk melihat pengaruh ukuran perusahaan, pertumbuhan aktiva dan profitabilitas, secara simultan terhadap struktur modal pada perusahaan Wholesale and Retail Trade yang terdaftar di Bursa Efek Indonesia untuk periode 2012-2014.

\section{HASIL PENELITIAN DAN PEMBAHASAN}

\section{GAMBARAN UMUM SAMPEL PENLITIAN}

Tabel2. Perusahaan Sampel

\begin{tabular}{|l|l|}
\hline NO. & Nama Perusahaan \\
\hline 1 & Ace Hardware Indonesia Tbk \\
\hline 2 & Sumber Alfaria Trijaya Tbk \\
\hline 3 & Catur Sentosa Adiprana Tbk \\
\hline 4 & Erajaya Swasembada Tbk \\
\hline 5 & Global Teleshop Tbk \\
\hline 6 & Hero Supermarket Tbk \\
\hline 7 & Mitra Adiperkasa Tbk \\
\hline 8 & M Cash Integrasi Tbk \\
\hline 9 & Midi utama Indonesia Tbk \\
\hline 10 & Mitra Komunikasi Nusantara \\
\hline 11 & Ramayana Lestari sentosa Tbk \\
\hline 12 & Supra Boga Lestari Tbk \\
\hline 13 & Sona Topas Tourism Industry Tbk \\
\hline 14 & Tiphone Mobile Indonesia Tbk \\
\hline 15 & Trikomsel Oke Tbk \\
\hline
\end{tabular}

Sumber :Indonesian Capital Market Directory 


\section{Uji StatistikDeskript}

\section{Tabel 3. Uji Statistik Deskriptif}

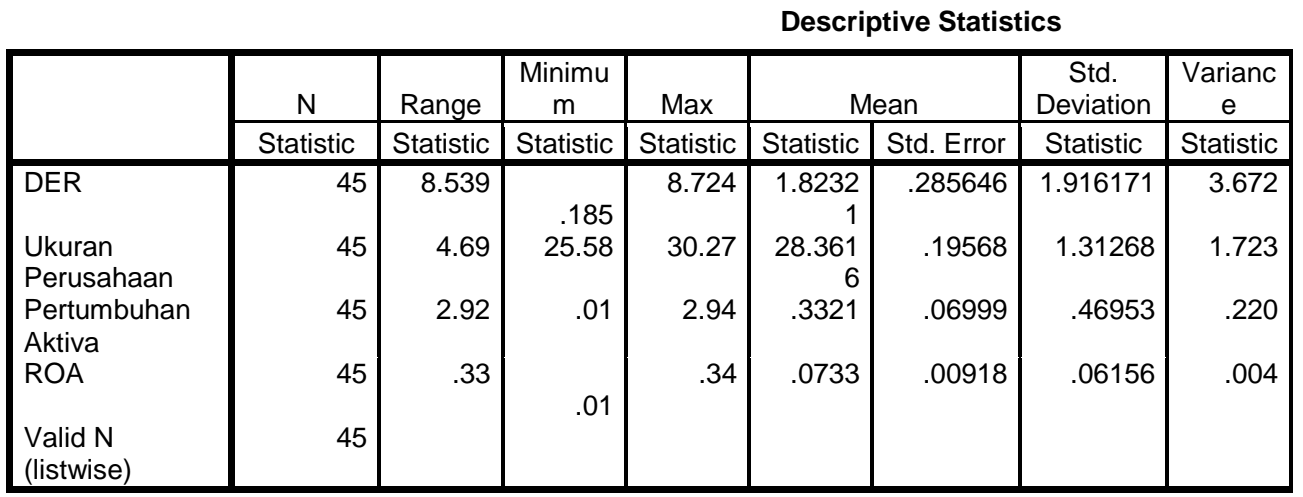

Sumber : Hasil penelitian dan sudahdiolah

Berdasarkan tabel 3, diperoleh DER rata-rata1.82321, Standar deviasi 1.916171, Ukuran perusahaan rata-rata28.3616, Standar deviasi 1.31268, Pertumbuhan Aktiva rata-rata.3321, Standardeviasi.46953, ROA ratarata.0733, Standardeviasi.06156.

\section{Hasil Uji Asumsi Klasik}

1. Normalitas

Uji normalitas bertujuan untuk menguji apakah dalam model regresi, variabel terikat dan variabel independen keduanya memiliki distribusi normal atau tidak. Model regresi yang baik adalah memiliki distribusi normal atau mendekati normal. Uji normalitas bertujuan untuk melihat apakah model regresi, variabelpenggangguatau residual berdistribusi normal.

\section{Gambar 1. Histogram}

Histogram

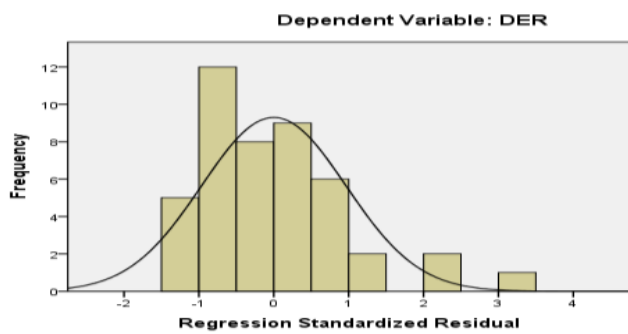

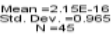

Sumber : Hasil penelitian dan sudah diolah 
Pada gambar 1 terlihatbahwavariabel terikat yaitu return saham mempunyai distribusi normal. Hal ini ditunjukkan oleh distribusi data tersebut tidak menceng ke kiriataukekanan.

\section{Multikolinieritas}

Multikolinearitas merupakan fenomena adanya korelasi yang sempurna antara satu variabel independen dengan variabel dependen lain. Jika terjadi multikolinearitas, akan mengakibatkan timbulnya kesalahan standar penaksir dan probabilitas untuk menerima hipotesis yang salah semakin besar. Berdasarkanhasilpengolahaan, data yang diperoleh, maka dapat dilihat pada :

Tabel4 TabelMultikolinearitas

Coefficients $^{\mathrm{a}}$

\begin{tabular}{|c|c|c|c|c|c|c|c|c|c|c|}
\hline \multirow[b]{2}{*}{ Model } & \multicolumn{2}{|c|}{$\begin{array}{l}\text { Unstandardized } \\
\text { Coefficients }\end{array}$} & \multirow{2}{*}{$\begin{array}{c}\begin{array}{c}\text { Standar } \\
\text { dized } \\
\text { Coeffici } \\
\text { ents }\end{array} \\
\text { Beta }\end{array}$} & \multirow[b]{2}{*}{$\mathrm{t}$} & \multirow[b]{2}{*}{ Sig. } & \multicolumn{3}{|c|}{ Correlations } & \multicolumn{2}{|c|}{$\begin{array}{l}\text { Collinearity } \\
\text { Statistics }\end{array}$} \\
\hline & B & $\begin{array}{l}\text { Std. } \\
\text { Error }\end{array}$ & & & & $\begin{array}{l}\text { Zero- } \\
\text { order }\end{array}$ & $\begin{array}{c}\text { Partia } \\
\text { । }\end{array}$ & Part & $\begin{array}{c}\text { Toleran } \\
\text { ce }\end{array}$ & VIF \\
\hline $\begin{array}{ll}1 & \text { (Constant) }\end{array}$ & 13.914 & 5.984 & & 2.325 & .025 & & & & & \\
\hline $\begin{array}{l}\text { Ukuran } \\
\text { Perusahaan }\end{array}$ & -.400 & .211 & -.274 & -1.897 & .045 & -.253 & -.284 & -.269 & .964 & 1.037 \\
\hline $\begin{array}{l}\text { Pertumbuhan } \\
\text { Aktiva }\end{array}$ & .038 & .592 & .009 & .064 & .949 & -.078 & .010 & .009 & .954 & 1.048 \\
\hline ROA & -10.457 & 4.459 & -.336 & -2.345 & .024 & -.319 & -.344 & -.333 & .980 & 1.021 \\
\hline
\end{tabular}

a. Dependent Variable: DER

Sumber : Hasil penelitian dan sudah diolah

Dari tabel tersebut dapat dilihat bahwa nilai VIF untuk masing - masing variabel adalah Ukuran Perusahaan1.037, Pertumbuhan Aktiva $=1.048$ dan $\mathrm{ROA}=1.021$ dan nilai masing - masing $<10$. Hal ini membuktikan bahwa model regresi yang digunakan dalam penelitian ini tidak terdapat gejala multikolinearitas (homoskedastisitas)

3. Autokorelasi

Penyimpanganautokorelasidalampenelitianinidiujidengan Durbin Watson (DW-test), diperoleh Durbin Watson sebesar 0,504. Hal ini ditunjukkan pada tabel berikut : 
Tabel 5. Tabel Durbin Watson

Model Summary ${ }^{b}$

\begin{tabular}{|c|c|c|c|c|c|c|c|c|c|c|}
\hline \multirow[b]{2}{*}{ Model } & \multirow[b]{2}{*}{$\mathrm{R}$} & \multirow[b]{2}{*}{ R Square } & \multirow[b]{2}{*}{$\begin{array}{l}\text { Adjusted } \\
\text { R Square }\end{array}$} & \multirow[b]{2}{*}{$\begin{array}{c}\text { Std. Error of } \\
\text { the } \\
\text { Estimate }\end{array}$} & \multicolumn{5}{|c|}{ Change Statistics } & \multirow[b]{2}{*}{$\begin{array}{l}\text { Durbin- } \\
\text { Watson }\end{array}$} \\
\hline & & & & & \begin{tabular}{|c|}
$\mathrm{R}$ \\
Squar \\
$\mathrm{e}$ \\
Chan \\
ge \\
\end{tabular} & $\begin{array}{c}\mathrm{F} \\
\text { Chan } \\
\text { ge }\end{array}$ & df1 & $\mathrm{df2}$ & $\begin{array}{c}\text { Sig. F } \\
\text { Change }\end{array}$ & \\
\hline 1 & $.419^{\mathrm{a}}$ & .176 & .116 & 1.802102 & .176 & 2.915 & 3 & 41 & .046 & .504 \\
\hline
\end{tabular}

Sumber : Hasil penelitian dan sudah diolah

4. Heteroskedastisitas

Untuk menentukan heteroskedastisitas dalam penelitian ini dilakukan dengan cara melihat ada tidaknya pola tertentu pada grafik scatterplot

Gambar 3. Hasil Heteroskedastisitas

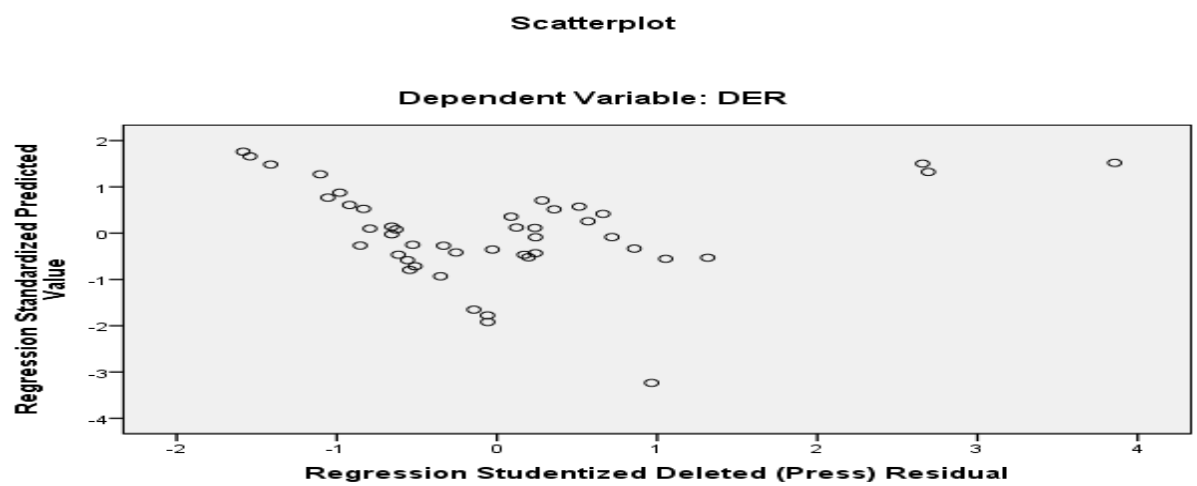

Sumber : Hasil penelitian dan sudah diolah

Dari gambar3 scatterplot, terlihatbahwatitik - titik menyebar secara acak dan tersebar di atasangka 0 pada sumbu Y. Hal ini dapat disimpulkan bahwa tidak terjadi heteroskedastiisitas pada model regresi, sehingga model regresi layak dipakai untuk memprediksi DER.

\section{AnalisisRegresi Linear Berganda}

Analisis ini digunakan untuk menghitung besarnya pengaruh ukuran perusahaan, pertumbuhan aktiva, profitabilitas terhadap struktur modal padaperusahaan Wholesale and Retail di Bursa Efek Indonesia. Berdasarkan pembatasan masalah dan hipotesis yang telah dikemukan sebelumnya diperoleh hasil pengolahan data tampak pada tabel 5.6 
Tabel 6. Variables Entered/Removed ${ }^{\mathrm{a}}$

\begin{tabular}{|l|l|l|l|}
\hline \multicolumn{3}{|c|}{ Variables Entered/Removed } \\
\hline 1 & \multicolumn{1}{|l|}{$\begin{array}{l}\text { Variables } \\
\text { Entered }\end{array}$} & $\begin{array}{c}\text { Variables } \\
\text { Removed }\end{array}$ & Method \\
\hline 1 & $\begin{array}{l}\text { ROA, Ukuran } \\
\text { Perusahaan, } \\
\text { Pertumbuhan } \\
\text { Aktiva }\end{array}$ & - & Enter \\
\hline
\end{tabular}

a. All requested variables entered.

\section{Sumber : Hasil Penelitian Dan Sudah Diolah}

Pada variabel enter/removed terlihat bahwa variabel - variabel yang dimasukkan (entered) adalah ROA, Pertumbuhan aktiva, dan ukuran perusahaan.

\section{Uji Determinan $\left(\mathbf{R}^{\mathbf{2}}\right)$}

Determinan digunakan untuk melihat seberapa besar pengaruh variabel bebas terhadap variabel terikat. Jika determinan $\left(\mathrm{R}^{2}\right)$ semakin besar atau mendekati satu, maka pengaruh variabel bebas (X1, X2 dan X3) terhadap variabel terikat $(\mathrm{Y})$ semakin kuat. Jika determinan $\left(\mathrm{R}^{2}\right)$ semakin kecil atau mendekati nol, maka pengaruh variabel bebas (X1, X2 dan X3) terhadap variabel terikat (Y) semakin lemah.

\section{Tabel 7. Uji Determinasi $\left(\mathbf{R}^{2}\right)$}

\begin{tabular}{|l|c|c|l|c|c|c|c|c|c|c|}
\hline \multicolumn{10}{|c|}{ Model Summary } \\
\hline
\end{tabular}

a. Predictors: (Constant), ROA, Ukuran Perusahaan, Pertumbuhan Aktiva

b. Dependent Variable: DER

\section{Sumber : Hasil Penelitian dan Sudah Diolah}

Nilai koefisien determinasi ( $R$ Square) sebesar .176 yang berarti variasi variabel ukuran perusahaan, pertumbuhan aktiva, profitabilitas dalam menjelaskan variasi variabel $D E R$ adalah sebesar $17,6 \%$ dan sisanya 82,4 $\%$ dijelaskan oleh variabel lain yang tidak diteliti dalam penelitian ini. Standar Error of Estimate (SEE) sebesar 1.8021029 Makin kecil nilai SEE akan membuat model regresi semakin tepat dalam memprediksi variabel dependen. 


\section{Pengujian Hipotesis \\ 6.1 Uji SignifikansiParsial (Uji t)}

Tabel8 Coefficients(a)

\begin{tabular}{|c|c|c|c|c|c|c|c|c|c|c|}
\hline \multicolumn{11}{|c|}{ Coefficients $^{a}$} \\
\hline \multirow[b]{2}{*}{ Model } & \multicolumn{2}{|c|}{$\begin{array}{l}\text { Unstandardized } \\
\text { Coefficients }\end{array}$} & \multirow{2}{*}{$\begin{array}{c}\begin{array}{c}\text { Standar } \\
\text { dized } \\
\text { Coeffici } \\
\text { ents }\end{array} \\
\text { Beta }\end{array}$} & \multirow[b]{2}{*}{$t$} & \multirow[b]{2}{*}{ Sig. } & \multicolumn{3}{|c|}{ Correlations } & \multicolumn{2}{|c|}{$\begin{array}{l}\text { Collinearity } \\
\text { Statistics }\end{array}$} \\
\hline & B & $\begin{array}{l}\text { Std. } \\
\text { Error }\end{array}$ & & & & $\begin{array}{l}\text { Zero- } \\
\text { order }\end{array}$ & Partial & Part & $\begin{array}{l}\text { Toler } \\
\text { ance }\end{array}$ & VIF \\
\hline 1 (Constant) & 13.914 & 5.984 & & 2.325 & .025 & & & & & \\
\hline $\begin{array}{l}\text { Ukuran } \\
\text { Perusahaan }\end{array}$ & -.400 & .211 & -.274 & -1.897 & .045 & -.253 & -.284 & -.269 & .964 & 1.037 \\
\hline $\begin{array}{l}\text { Pertumbuhan } \\
\text { Aktiva }\end{array}$ & .038 & .592 & .009 & .064 & .949 & -.078 & .010 & .009 & .954 & 1.048 \\
\hline ROA & -10.457 & 4.459 & -.336 & -2.345 & .024 & -.319 & -.344 & -.333 & 980 & 1.021 \\
\hline
\end{tabular}

a. Dependent Variable: DER

Sumber : Hasil penelitian dan sudah diolah

Berdasarkan hasil uji statistik pada tabel 5.8. menunjukkan bahwa t-hitung variable nilai ukuran perusahaan(X1) dengan koefisien regresi .400 tingkat signifikansi $0.045>0.05$ maka H0 ditolak. Dengan demikian, ukuran perusahaan berpengaruh signifikan terhadap struktur modal pada perusahaan Wholesale And Retail Trade yang terdaftar di Bursa Efek Indonesia (BEI).

Berdasarkan hasil uji statistik pada tabel 5.8. menunjukkan bahwa t-hitung variabel nilai pertumbuhan aktiva (X2) dengan koefisien regresi .038tingkat signifikansi .949> 0.05 maka H0 diterima. Dengandemikianpertumbuhanakivatidak berpengaruh terhadap struktur modal pada perusahaan Wholesale And Retail Trade yang terdaftar di Bursa Efek Indonesia (BEI).

Berdasarkan hasil uji statistik pada tabel 5.8. menunjukkan bahwa t-hitung variabel nilai $R O A$ (X3) dengan koefisien regresi -10.457tingkat signifikansi .024< 0.05 maka H0 ditolak. Dengan demikian ROA berpengaruhsignifikanterhadapstruktur modal pada perusahaanWholesale And Retail Trade yang terdaftar di Bursa Efek Indonesia (BEI). 


\subsection{Uji Signifikansi Simultan (Uji-F)}

Tabel. 9. Anova

ANOVA $^{b}$

\begin{tabular}{|ll|r|r|r|r|l|}
\hline \multicolumn{2}{|l|}{ Model } & \multicolumn{1}{|c|}{$\begin{array}{c}\text { Sum of } \\
\text { Squares }\end{array}$} & Df & Mean Square & F & Sig. \\
\hline 1 & Regression & 28.405 & 3 & 9.468 & 2.915 & $.046^{\mathrm{a}}$ \\
& Residual & 133.150 & 41 & 3.248 & & \\
& Total & 161.555 & 44 & & & \\
\hline
\end{tabular}

a. Predictors: (Constant), ROA, Ukuran Perusahaan, Pertumbuhan Aktiva

b. Dependent Variable: DER

Sumber : Hasil Penelitian Dan Sudah Diolah

Tabel 9. menunjukkan bahwa tingkat signifikansi $.046^{\mathrm{a}}<0,05$ sehingga dapat dinyatakan bahwa H0 ditolak. Artinya secara simultan terdapat pengaruh yang signifikan antara ukuran perusahaan, pertumbuhan aktiva, $R O A$ terhadap DER.

\section{Pembahasan}

1. Pengaruh ukuran perusahaan Terhadap DER Pada Perusahaan Wholesale And Retail Trade yang Terdaftar Di Bursa Efek Indonesia

Teori asimetri (asymmetric theory) mengasumsikan bahwa perusahaan yang lebih besar memiliki ketidakseimbangan informasi yang lebih kecil. Hal ini memudahkan perusahaan dalam hal pendanaan eksternal. Oleh karena itu, ukuran perusahaan yang besar merupakan sinyal positif bagi kreditur untuk memberikan pinjaman. Ukuran perusahaan diproksikan dengan nilai logaritma natural dari total aset. Logaritma dari total aset dijadikan indikator dari ukuran perusahaan karena jika semakin besar ukuran perusahaan maka aset tetap yang dibutuhkan juga akan semakin besar. Berdasarkan hasil uji statistik menunjukkan bahwa ukuran perusahaan mempunyai t-hitung - 1.897 , dengan koefisien regresi $-0,400$ dan tingkat signifikansi 0,045 $<0,05$ maka H0 diterima. Dengan demikian Ukuran Perusahaan berpengaruh negatif signifikan terhadap DER. pada Perusahaan Wholesale And Retail Trade yang Terdaftar di Bursa Efek Indonesia tahun 2012 - 2014. Hasil penelitian ini tidak mendukung teori asimetri yang menyatakan semakin besar ukuran perusahaan maka semakin mudah menggunakan pendanaan eksternal. Hal ini disebabkan tidak semua perusahaan yang mempunyai assets besar suka menggunakan pendanaan eksternal tetapi lebih suka menggunakan internal financing (pendanaan dari hasil operasi perusahaan). Penelitian sejalan dengan penelitian Hakim 
(2013) yang menyatakan ukuran perusahaan berpengaruh negatif signifikan terhadap struktur modal.dan tidak sejalan dengan penelitian yang dilakukan Daulay (2009) yang menyatakan bahwa ukuran perusahaan berpengaruh positif signifikan terhadap struktur modal pada Perusahaan Wholesale And Retail Trade yang Terdaftar di Bursa Efek Indonesia tahun $2012-2014$.

\section{Pengaruh Pertumbuhan Aktiva Terhadap Debt To Equity Ratio Pada Perusahaan Wholesale And Retail Trade yang Terdaftar Di Bursa Efek Indonesia}

Pecking order theory menyatakan bahwa perusahaan dengan tingkat pertumbuhan yang tinggi akan melakukan ekspansi dengan cara menggunakan dana eksternal berupa hutang. Terjadinya peningkatan asset yang diikuti peningkatan hasil operasi akan semakin menambah kepercayaan pihak luar terhadap perusahaan. Pertumbuhan aktiva diukur dengan rasio pertumbuhan yang menggambarkan kemampuan perusahaan mempertahankan posisi ekonominya ditengah pertumbuhan ekonomi dan sektor usahanya. Berdasarkan hasil uji statistik menunjukkan bahwa Pertumbuhan Aktiva mempunyai t-hitung 0,064 dengan koefisien regresi 0.038 dan tingkat signifikansi $0.949>0.05$ maka H0 diterima. Dengan demikian Pertumbuhan Aktiva tidak berpengaruh positif tidak signifikan terhadap struktur modal pada Perusahaan Wholesale And Retail Trade yang Terdaftar di Bursa Efek Indonesia tahun 2012 - 2014. Hasil penelitian ini tidak sejalan dengan Pecking order theory yang menyatakan semakin tinggi tingkat pertumbuhan perusahaan, semakin menggunakan dana ekternal. Hal ini disebabkan tidak semua perusahaan yang mempunyai pertumbuhan aktiva tinggi suka menggunakan dan eksternal karena banyak perusahaan yang mempunyai assets yang besar dapat membiayai modalnya dengan laba perusahaan. Penelitian ini sejalan dengan penelitian panjaitan (2015) yang menyatakan bahwa pertumbuhan aktiva berpengaruh positif tidak signifikan terhadap struktur modal. Dan tidak sejalan dengan penelitian Daulay (2009) yang menyatakan bahwa pertumbuhan aktiva berpengaruh positif signifikan terhadap struktur modal pada Perusahaan Wholesale And Retail Trade yang Terdaftar di Bursa Efek Indonesia tahun 2012 - 2014. 


\section{Pengaruh Return On Assets TerhadapDebt To Equity Ratio Pada Perusahaan Wholesale And Retail Trade yang Terdaftar Di Bursa Efek Indonesia}

Pecking order theory menjelaskan perusahaan-perusahaan yang profitable umumnya meminjam dalam jumlah sedikit. Hal tersebut bukan disebabkan karena mereka mempunyai target debt ratio yang rendah, tetapi karena mereka memerlukan external financing yang sedikit. Profitabilitas dalam penelitian ini diukur dengan rasio Hasil Pengembalian atas Aset (Return on Assets) yang merupakan rasio yang menunjukkan hasil (return) atas penggunaan aset perusahaan dalam menciptakan laba bersih. Berdasarkan hasil uji statistik menunjukkan bahwa Return On Assets mempunyai t-hitung 2,345 dengan koefisien regresi -10.457 dan tingkat signifikansi $0.024<0.05$ maka H0 ditolak. Dengan demikian Return On Assets berpengaruh negatif signifikan terhadap struktur modal pada Perusahaan Wholesale And Retail Trade yang Terdaftar di Bursa Efek Indonesia tahun 20102- 2014. Hasil penelitian ini sejalan dengan teori Pecking order theory yang menyatakan perusahaan yang semakin profitable akan menggunakan hutang semakin sedikit. Penelitian ini sejalan dengan penelitian Hakim (2013) yang menyatakan bahwa profitabilitas berpengaruh negatif signifikan terhadap struktur modal pada Perusahaan Wholesale And Retail Trade yang Terdaftar di Bursa Efek Indonesia tahun 20102- 2014.

\section{KESIMPULAN DAN SARAN}

\section{Kesimpulan}

Berdasarkan hasil pembahasan, dapat disimpulkan bahwa:

1. Nilai koefisien determinan menunjukkan $17,6 \%$ dapat dijelskan ukuran perusahaan, pertumbuhan aktiva, profitabilitas dan sisanya 82,4\% dijelaskan oleh variabel lain yang tidak diteliti dalam penelitian ini.

2. Ukuran Perusahaan berpengaruh signifikan terhadap Debt To Equity Ratio pada perusahaan Retail And Wholesale di Bursa Efek Indonesia.

3. Pertumbuhan Aktiva tidak berpengaruh terhadap Debt To Equity Ratio pada perusahaan Retail And Wholesale di Bursa Efek Indonesia.

4. Return On Assets berpengaruh signifikan terhadap Debt To Equity Ratio pada perusahaan Retail And Wholesale di Bursa Efek Indonesia.

5. Ukuran Perusahaan, Petumbuhan Aktiva dan Return On Assets berpengaruh signifikan terhadap Debt To Equity Ratio pada perusahaan Retail and Wholesale di Bursa Efek Indonesia, dapat diterima pada tingkat signifikansi 5 persen. 
Saran

Sebaiknya peneliti selanjutnya menambah variabel penelitian, menambah tahun penelitian dan melakukan penelitian dengan objek berbeda.

\section{DAFTAR PUSTAKA}

Brigham, Eugene G., dan Joel F. Houston, 2001, Manajemen Keuangan, Edisi Kedelapan, Erlangga, Jakarta.

Ghozali, Imam, 2005, Aplikasi Analisis Multivariate Dengan Program SPPS, edisi ketiga. Indonesia: Universitas Diponegoro.

Harahap, Nakman, 2003. Analisis Pengaruh Struktur Modal Terhadap Profitabilitas Pada Industri Pulp And Paper Yang Masuk Pasar Modal Indonesia.Tesis Mahasiswa FE USU.

Purhadi, Imam, 2006. Pengaruh Struktur Modal Terhadap Profitabilitas Perusahaan Barang Konsumsi Terbuka Di Bursa Efek Jakarta. Tesis Mahasiswa FE Universitas Terbuka.

Riyanto, Bambang, 2001. Dasar-Dasar Pembelanjaan Perusahaan, Edisi Keempat, Cetakan Ketujuh, Yogjakatra: BPFE.

Sawir, Agnes, 2003. Analisa Kinerja Keuangan Dan Perencanaan Keuangan Perusahaan, Cetakan Ketiga, Indonesia: PT. Gramedia Pustama Utama.

Setiyono, Gunawan, 2007. Pengaruh Perputaran Modal Kerja Dan Struktur Modal Terhadap Profitabilitas (Studi Empiris Pada Perusahaan Food And Beverage yang Listing Di Bursa Efek Jakarta). Skripsi Mahasiswa FE UMM.

Supranto, J.2001. Statistik: Teori Dan Aplikasi.Jilid Satu, Edisi Keenam, Jakarta: Erlangga.

Sawidji, Widoatmodjo, 2004. JurusJito Go Publik,Indonesia: JurnalindoAksaraGrafika.

Saidi, 2004, Faktor-Faktor Yang Mempengaruhi Struktur Modal Pada Perusahaan Manufaktur Go Publik Di Bej Tahun 1997-2002, NO.1 VOL 11.Maret.

Sartono, R. Agus, 1996, Manajemen Keuangan Teori Dan Aplikasi, Edisi 3, BPFE, Jogjakarta.

Sugiyarso, G., dan F. Wunarni, 2005. Manajemen Keuangan, Edisi Pertama, Cetakan Pertama, Yogjakarta: Media Pressindo.

Susetyo, Arief, 2009, Faktor-Faktor Yang Mempengaruhi Struktur Modal Pada Perusahaan Manufaktur Yang Go Publik Di Bej Perode 2000-2003, Skripsi, Universitas Islam Indonesia, Yogjakarta. 